\title{
ポリグルタミン酸繊維の湿式紡系条件*
}

\author{
京都工芸㵶維大学蟣維学部 \\ 高橋重三・山崎隆 \\ 武内氐男・相宅省吾
}

\section{WET SPINNING OF POLYGLUTAMIC ACID FIBER}

By Jüzō Takahashi, Takashi Yamazaki, Tamio Takeuchi and Seigo Ōya

(Faculty of Textile Science, Kyoto University of Industrial Arts and

Textile Fibers, Matsugasaki, Sakyo-ku, Kyoto, Japan)

The polyglutamic acid (PGA) fibers were spun from concentrated poly-sodium-L-glutamate (PSLG) aqueous solution, using inorganic acids such as $\mathrm{HCl}, \mathrm{H}_{2} \mathrm{SO}_{4}$ and $\mathrm{H}_{3} \mathrm{PO}_{4}$, as coagulant. The relations between the spinning conditions, such as drafting and drawing and the properties of the spun fibers, such as the molecular conformation the crystallinity and the mechanical properties were investigated.

The molecular chains of undrafted and undrawn fibers have the $\alpha$-helix conformation regardless of acids used as coagulant, and the crystals were unoriented. On the other hand, the conformation of molecular chains of drafted and drawn fibers depended on acids as coagulant. The crystals comprised of molecular chains with $\beta$-structure were formed and the well-oriented fiber was obtained when $\mathrm{H}_{3} \mathrm{PO}_{4}$ was used as coagulant. The crystals of $\mathrm{H}_{2} \mathrm{SO}_{4}$-coagulated fiber were a mixture of $\alpha$-helix and $\beta$-structure. However, with $\mathrm{HCl}$-coagulant the $\alpha$-helix conformation did not change and the crystals were oriented.

The mechanical properties and the stability of the fibers against hot water varied widely depending on the acids used as coagulant and the spinning conditions. The fiber spun with $\mathrm{H}_{3} \mathrm{PO}_{4}$ coagulant was more stable against water than those spun with other coagulants.

(Received October 7, 1971)

\section{1. 緒言}

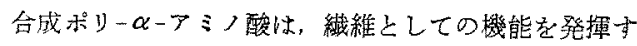
るのに必要な重合体として具備すべき数々の特性を持っ ているから，各種の重合体について瀻維化の研究が行な

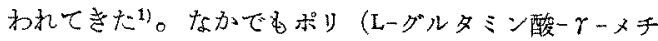
ル) (PMLG) の緎維化以関する研究は多数行なかれてい る2。しふし績維として具借すべき基本特性たとえば吸 湿性，染色性などに考慮言べき点があるように思われ る。

PMLG 水溶性化したポり（しーグルタミン酸ナトリウ ム) (PSLG) 在原料ポリマーとして瀻䧽化し，积りグル タミン酸 (PGA) 傤維を得ようとする試みは特部 られるにすぎ妃いPSLG 存料ポりマー之する緎維化 の方法としては，それが水溶性であり，溶融しない点か

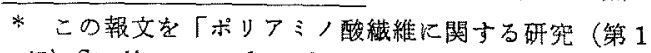
報) Studies on polyamino acid fibers (part 1)」と する。
ら湿式紡系法が適当であるPSLG は直鎖状高分子で適 度な柔軟性をるち，かつ倪能基を持つポリマーである。

PSLG から PGA への化学变化は酸によって行なかれ

$$
\begin{aligned}
& \left.+\mathrm{NH}-\mathrm{CH}-\mathrm{CO})_{n} \quad+\mathrm{NH}-\mathrm{CH}-\mathrm{CO}\right)_{\frac{1}{n}}
\end{aligned}
$$

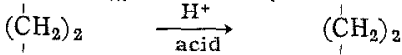

$$
\begin{aligned}
& \text { COONa } \mathrm{COOH} \\
& \text { (PSLG) (PGA) }
\end{aligned}
$$

ることは，化学式からあ容易に考えられることである。 しかし，湿式紡禾におけ瀻維形成過程证複䧴で, 得られ

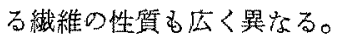

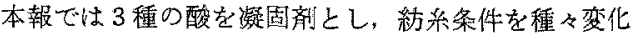
させて得られた䋐維について，紡糸性，分子鎖の二次構 造の変化, 㵶維性能などを検討した結果と, これから考 察した䄉維形成機搆について報告する。

\section{2. 実 験 方 法}

2.1 試 料

ボリ(しーグルタミン酸ーケーヌチル) (PMLG) 二程化工 
チレン溶夜からメタノールで PMLGを分離した。フレ 一ク状 PMLGをアルコール性アルカリにて不均一ケン

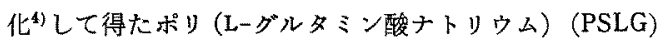
を試料とした。分子量は $0.2 \mathrm{M}$ 塩化ナトリゥム水溶夜 （pH 7.3）を溶媒とし， $20^{\circ} \pm 0.05^{\circ} \mathrm{C}$ で粘度を測定し， 四点希积法で固有粘度 $[\eta]$ を求め, 和田 ${ }^{5)}$ の侙から求め た結果 $\bar{M}_{w}=45000$ であった。

\section{2 紡系原液}

上記試料の $35 \%$ 水溶液を脱泡し原液とした。粘度は B型粘度計を用い $20^{\circ} \mathrm{C}$ で則定した結果 38 ポイズであっ た。原液の $\mathrm{pH}$ は約 8.5 であった。重合体浱度と粘度の 関係を図 1 亿示した。

\section{3 紡系装置および条件}

小型試験紡系装置を使用した。装置の概要を図 2 に示 した。紡系原液をギヤ゙ポンブで定量送り、キャンドル フィルターを通しノズル3から凝固浴中に押出した。第

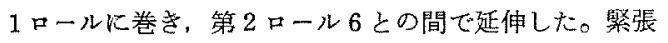
しながら 7 のボビンに卷取り、ボビンとともに流水にて 水洗したのち風乾した。特もな紡系条件を表1 亿示し た。

\section{4 織維性能測定法}

強伸度, ヤング斋：島津オートグラフ IM-100 型を使 用し， $20^{\circ} \mathrm{C}, \mathrm{RH} 65 \%$ で武料長 $5 \mathrm{~cm}$, 引張速度 $100 \%$ minて測定した。応力ひずみ曲線の立上り部分から初期 弾性率 (ヤング率) を求めた。

$\mathrm{X}$ 線回折: 理学電機卓上型 $\mathrm{X}$ 線発生装置および 0.5

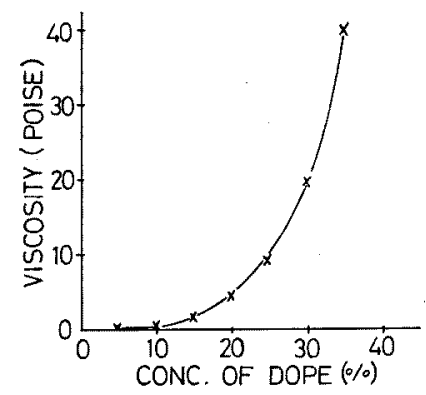

Fig.1. Change of viscosity with concentration of PSLG dissolved in water $\left(20^{\circ} \mathrm{C}\right)$.

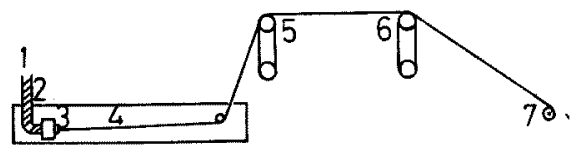

Fig. 2. Apparatus for spinning.
1. Gear pump
2. Dope
3. Nozzle
4. Coagulating bath
5. First roller
6. Second roller
7. Bobbin

Table 1. Spinning condition

\begin{tabular}{|c|c|c|}
\hline Dope & $\begin{array}{ll}\text { Polymer } & \bar{M}_{w} \\
\text { Solvent } & \\
\text { Concentration } & (\%, \mathrm{w} / \mathrm{w}) \\
\text { Viscosity } & \left(\text { Poise }, 20^{\circ} \mathrm{C}\right)\end{array}$ & $\begin{array}{l}45,000 \\
\text { Water } \\
35 \\
38\end{array}$ \\
\hline $\begin{array}{c}\text { Coagu- } \\
\text { lation }\end{array}$ & $\begin{array}{l}(\mathrm{cm}) \\
\left({ }^{\circ} \mathrm{C}\right) \\
(\mathrm{mm} \phi \times \text { holes }) \\
(\mathrm{cc} / \mathrm{min})\end{array}$ & $\begin{array}{l}\mathrm{HCl}, 4 \mathrm{~N} \\
\mathrm{H}_{2} \mathrm{SO}_{4}, 4 \mathrm{~N} \\
\mathrm{H}_{3} \mathrm{PO}_{4}, 43 \\
\%(\mathrm{w} / \mathrm{w}) \\
100 \\
20 \\
0.07 \times 50 \\
1.2\end{array}$ \\
\hline $\begin{array}{l}\text { Win- } \\
\text { ding }\end{array}$ & $\begin{array}{ll}\text { First-roller speed } & (\mathrm{m} / \mathrm{min}) \\
\text { Second-roller speed } & (\mathrm{m} / \mathrm{min}) \\
\text { Bobbin speed } & (\mathrm{m} / \mathrm{min})\end{array}$ & $\begin{array}{l}6 \sim 100 \\
6 \sim 100 \\
6 \sim 100\end{array}$ \\
\hline
\end{tabular}

Table 2. Model fiber-forming properties of PSLG solution using three kinds of acids as coagulant

\begin{tabular}{l|c|c|l}
\hline \multicolumn{2}{c|}{$\begin{array}{c}\text { Coagulant } \\
\text { (vol. } \%)\end{array}$} & $\begin{array}{c}\text { Whitening time } \\
\text { (min) }\end{array}$ & Notes \\
\hline \multirow{4}{*}{$\mathrm{HCl}$} & 12 & 7 & \\
& 6 & $9 \sim 10$ & Inflexible \\
& 1.5 & 13 & \\
\hline \multirow{3}{*}{$\mathrm{H}_{2} \mathrm{SO}_{4}$} & 20 & $9 \sim 10$ & Somewhat \\
& 15 & $9 \sim 10$ & flexible \\
& 10 & 15 & \\
\hline & 50 & Transparent & \\
$\mathrm{H}_{3} \mathrm{PO}_{4}$ & 37 & Semitransparent & Flexible \\
& 16 & Semitransparent & \\
\hline
\end{tabular}

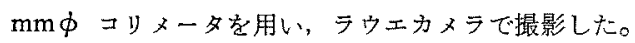

赤外吸取スペタトル：島津 IR-27 型を用い，錠剂法で 測定した。

熱水收縮率：試料 $1 \mathrm{~m}$ をガーゼに包及沸腾水中に 30 分間浸せきし，濾紙上で風乾したあとの試料長と，処理 前の試料長から算出した。

\section{3. 結果および考察}

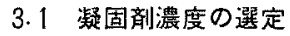

㠜固剂々しての酸濃度を变化し, 得られる凝固体の状 態を定性的に钼察した。約 $500 \mathrm{cc} の$ 所定漕度の酸浴中 に, 注射針を用い原液を押し出し, 系条の状態老観察し た結果を表 2 に示した。

塩酸特よび硫酸は濃度によって白化時間に多少の差は 
あるが，ほぼ７15 分を要し得られた采条は柔軟性がな い。それらに比較して、リン酸で㠜固したものは半透明 または透明であり白化現象は見られなかった。得られた 采条は非常渘軟性汇富んでいる。

PGA 繊維の湿式紡系では，酸によって PSLG から PGA に変化する化学反応による凝固と，脱溶媒ならび に脱塩による物理的凝固の両者が考兄られる。したがっ て凝固剂の凝固能力を評価する場合にはこの両者を考虑 する必要がある。従来湿式紡系に括ける凝固郕の凝固力 を評価する方法6)として，大量の凝固剂中に重合体溶液 を一滴打としょく振とうして，凝固に至るときの凝固郕 濃度をるって評価する方法，またある重合体濃度の溶液 一定量に凝固剤をかきまぜながら滴下して，白濁または ゲル化などの状態変化を抗こすに要した凝固剤の滴下量 をもって評価する方法が用いられてきた。PSLG の濃厚 溶液についても同様検討してみたが一義的に評価するこ とは困難であった。

リン酸は $0.1 \mathrm{~mol} / l$ 程度の濃度において, 同濃度の塩 酸に比べ解離は約 $1 / 3$ であることと, 上の結果とを考慮 乙, $\mathrm{H}^{+}$濃度がほぼ近いと思われる溶液濃度として表 1 の凝固剂濃度を選定した。湿式紡采に打ける凝固剤の種 類, 組成などは繊維形成の重要な因子であるから，これ らに関しては続報で報告する予定である。

\section{2 紡 系性}

紡系性は最大ドラフト比(巻取速度/理論吐出速度)を もって表わした。結果を表 3 に示した。最大ドラフト比 はく塩酸く硫酸くリン酸の順であることがわかる。リン 酸浴では紡系速度 $100 \mathrm{~m} / \mathrm{min}$ 以上でも紡系可能である。

紡系性は凝固剤の組成, 温度㧍よび反応時間のほか, 紡系原液の性質によっても影響されるので，これらの因 子を検討しなければ相違の理由を明確にすることはでき ないが，従来の湿式紡系に関する知見 ${ }^{6)}$ から次のように 考えられる。塩酸浴では $\mathrm{H}^{+}$濃度が高いため吐出直後の 采条表面ですみやかに化学反応が倣こり PGA の表皮層 を形成する。この表皮層は表 2 に示したように柔軟性が 劣る。また脱溶媒が弱く, 系条内部は溶媒が多量に含ま れ，原液と同じ流体に近い状態にあるるのと考えれば， ドラフトによる張力は主として系条表面にかかるため大 きく引き伸ばされ得ない。したがって紡䒺性が小さいも のと考えられる。リン酸は $43 \%(5.6 \mathrm{~mol} / l)$ の濃度では，

Table 3. Effect of coagulants on the maximum draft ratio

\begin{tabular}{c|c|c|c}
\hline Coagulant conc. & $\mathrm{HCl}, 4 \mathrm{~N}$ & $\mathrm{H}_{2} \mathrm{SO}_{4}, 4 \mathrm{~N}$ & $\mathrm{H}_{3} \mathrm{PO}_{4} 43 \%$ \\
\hline Max. draft ratio & 5.8 & 13.3 & 16.7 \\
\hline
\end{tabular}

Spinning conditions are listed in Table 1.

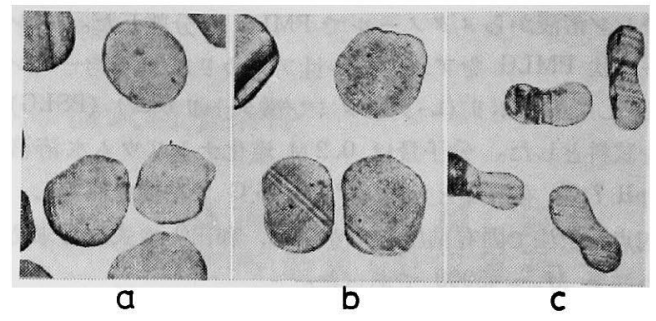

Fig. 3. Cross-sectional figures of PGA fibers obtained using different spinning conditions.

(a) : Coagulant $\mathrm{HCl} 4 \mathrm{~N}$, Draft ratio 1.3 , Draw ratio 3.0

(b) : Coagulant $\mathrm{H}_{2} \mathrm{SO}_{4} 4 \mathrm{~N}$, Draft ratio 1.3 , Draw ratio 3.0

(c) : Coagulant $\mathrm{H}_{3} \mathrm{PO}_{4} 43 \%$, Draft ratio 2.7, Draw ratio 2.5

$\mathrm{H}^{+}$濃度は $4 \mathrm{~N}$ 塩酸のそれよりも低いるのと考えられる。 したがってリン酸浴中では采条表面の化学反応は塩酸よ りも遅くなるものと思われる。また濃度が高いことから 脱溶媒力が強く流体系の表面はゲル状表面となり，内部 は濃厚溶液あるいはゲルに近い状態にあるるのと考㝋れ ぱ，ドラフトによる張力は系条全体にかかるため大きく 引き伸ばされ紡采性が大きいるのと考えられる。

\section{3 断面形状}

塩基性染料 Rhodamine BH conc で染色した 3 種の 瀻維の断面顕微鏡写真を㘡 3 に示した。各繊維の扰もな 紡系条件は写真の下に示してある。

（a）扰よび (b) は図 2 の装置を用い，凝固郕として 4 $\mathrm{N}$ 塩酸打よび $4 \mathrm{~N}$ 硫酸を用い,ドラフト比 $(3.2$ で定義 した） 1.3 で第 1 ロールに巻さ，引き続き第 2 ロールの 巻取速度を 3 倍にして延伸した試料である。(c) は同じ 装置を用い，43\% リン酸を凝固剤とし，ドラフト比 2.7 で第 1 ロールに巻き，引き続き第 2 ロールの巻取速度を 2.5 倍にして延伸した試料である。

この写真から塩酸扣よび硫酸を㠜固浴とした瀻維の断 面は円形であり，内部むほぼ均一の上うに思われる。リ ン酸を凝固浴として紡系した瀻維の断面は典型的な中央 くびれ型（まゆ型，亜鈴型）で，内部は均一と思われる。 等方性のモデル系に扣いても全く同様に観察された。こ のよらに凝固剤の種類により断面形状がはっきりと相違 することがわかった。

塩酸括よび硫酸浴では采条表面ですみやかに化学反応 が起り, さらに比較的すみやかに $\mathrm{H}^{+}$が内部に桩散し PGA の沈殿体を生成する。つついて延伸により溶媒な らびに塩類がしぼり出され体積収縮がおこるものと考兄 れば断面は円形になるだろう。リン酸凝固浴では脱溶媒 が優先し, 表面のみが先に凝固し, 後から化学反応と脱 
溶媒ならびに脱塩類が起るため亜鈴型になるものと思わ れる。

\section{4 二次構造の相異}

天然および合成ポリー $\alpha-ア ミ ノ$ 酸の分子鎖は, 希薄溶 液中においてはランダムコイルあるいは $\alpha$-ヘリックス 状態を，固体に拈いてはこれらのほかさらに及一構造を

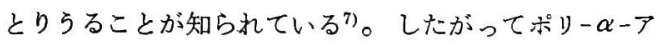

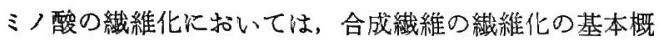
念に加えて, 分子鎖の二次構造の相違による凝集状態の 相違を考虑する必要がある。

\subsection{1 紡系原液中の二次構造}

希薄溶液中の分子鎖の形態に関しては旋光性, 固有粘 度などの測定手段により $\alpha$ にリックスとランダムコイ ル状態が区別されている7。紡系原液中の二次構造は, 紡系性ならびに繊維の性質に扣よぼす影響が大きく，ポ リアミノ酸の絨維化に拈いては重要な因子である。濃厚 溶液中に括ける形態を直接区別する方法は確立されてい ないので，著者らは次の方法により識別した。

重合体濃度と粘度の関係を測定し図 1 のような結果を 得た。この結果濃度数\%から約 $40 \%$ をで連続して粘度 が上昇することがわかる。したがってこの濃度範囲内に 拈いては二次構造は変化しないものと考えられる。著 者 $^{8)}$ らが PMLG の二塩化ェチレン (EDC) 溶液について 同様に測定した結果では，濃度約 $12 \%$ に扣いて粘度が 急変することを見出し，またこの濃度以上では光学的異 方性が現われることを確認した。したがってこの PMLG の EDC 溶液では二次構造が濃度によって变化するもの と考えた9。また Doty ${ }^{10)}$ らの研究からポりグルタミン 酸の希薄溶液に括いては， $\mathrm{pH}$ の大きいところでは分子 鎖はランダムユイル状態として溶解しているので，われ われの紡糸原液の $\mathrm{pH}$ が約 8.5 であることを考慮すれ ば, 原液中の分子鎖の形態はランダムコイル状態であろ らと推定される。また光学的異方性が認められなかった ことからる上のように推定される。

\section{4 .2 繊維中の二次構造}

X線回折写真护よび IR スペクトルを測定し表 $4^{11}$ 亿 よって $\alpha$ ーヘリックスと $\beta$-構造を識別した。

Table 4. Spacings in $X$-ray and IR spectra of $\alpha$-helix and $\beta$-coil structure of PGA

\begin{tabular}{l|c|c}
\hline & $\alpha$-helix & $\beta$-coil \\
\hline \multirow{2}{*}{ Spacings } & & $7.8 \mathrm{~A}$ \\
& $9.7 \mathrm{~A}$ & $4.7 \mathrm{~A}$ \\
& & $3.9 \mathrm{~A}$ \\
\hline \multirow{2}{*}{ IR spectra $\left(\mathrm{cm}^{-1}\right)$} & $1650 \sim 60$ & 1630 \\
& $1540 \sim 50$ & $1520 \sim 30$ \\
\hline
\end{tabular}

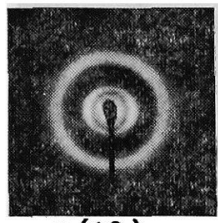

$a(1.0)$

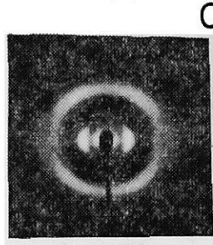

$d(1.0)$

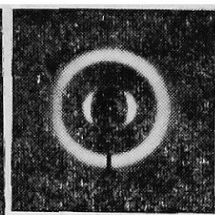

$b(2.7)$

Coagulant : $\mathrm{HCl}$

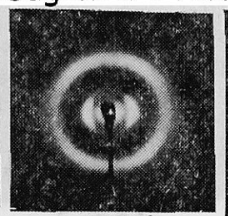

e (2.7)

Coagulant : $\mathrm{H}_{2} \mathrm{SO}_{4}$

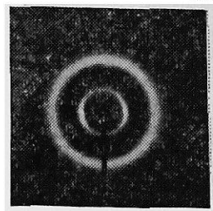

$g(1.0)$

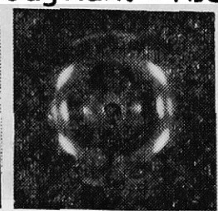

$h(8.3)$

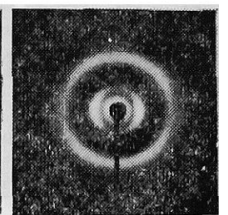

c(5.8)

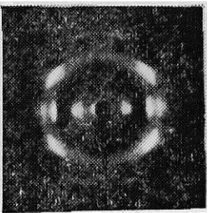

$f(12.5)$

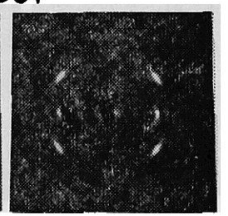

\section{Coagulant : $\mathrm{H}_{3} \mathrm{PO}_{4}$}

Fig. 4. Changes of $\mathrm{X}$-ray fiber diagrams of PGA fibers obtained using different spinning conditions.

No. in ( ) are draft ratio.

$\mathrm{a} \sim \mathrm{c}$ : Coagulant $\mathrm{HCl} 4 \mathrm{~N}$, Draft ratio $1 \sim 5.8$, Draw ratio 1

$\mathrm{d} \sim \mathrm{f}$ : Coagulant $\mathrm{H}_{2} \mathrm{SO}_{4} 4 \mathrm{~N}$, Draft ratio $1 \sim$ 12.5, Draw ratio 1

g i : Coagulant $\mathrm{H}_{3} \mathrm{PO}_{4} 43 \%$, Draft ratio $1 \sim$ 12.5, Draw ratio 1

PGA の $\alpha$ ーヘッックスの結晶構造については， X線解 析により単位胞の大きさが決定されていないので, 赤道 上 $9.7 \mathrm{~A}$ に相当する所に回折が現われるものを $\alpha$ ○リ ックスの結晶と仮定した。

a 、凝固剤およびドラフトと二次構造

3 種の凝固剂を用い，ドラフト比だけを変化し延伸し ない繊維のX線回折写真を図 4 に示した。この結果か ら，ドラフト比 1 すなわらノズルから押し出したたけで は，いずれの凝固剂を用いても，結晶内に虰壮る分子鎖 は $\alpha$ ーリックスと思われるものであり結晶はほとんど 配向していないことがわかる。程酸凝固浴では最高ドラ フト比 5.8 に拈いてもム-ヘリックスと思われるもので ある。硫酸浴では最大ドラフト比 12.5 においては, か なり $\beta$-構造が混在することがわかる。リン酸浴ではド ラフトのみによっても忹とんど $\beta$ 一構造になることがわ かる。

このよらな凝固剤の種類およびドラフトによる二次構 


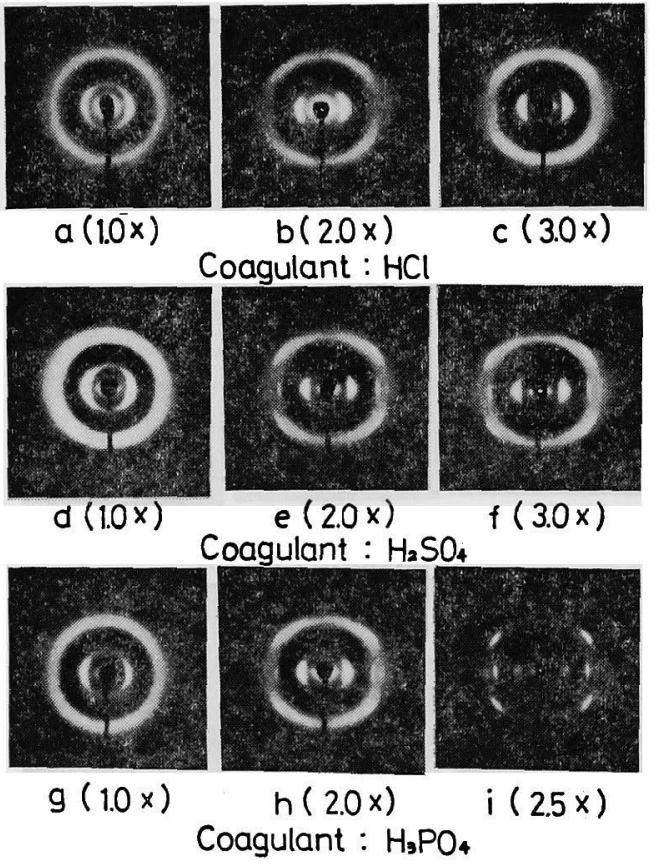

Fig. 5. Changes of X-ray fiber diagrams of PGA fibers obtained using different spinning conditions.

No. in ( ) are draw ratio.

$\mathrm{a} \sim \mathrm{c}$ : Coagulant $\mathrm{HCl} 4 \mathrm{~N}$, Draft ratio 1.3

Draw ratio $1 \sim 3$

$\mathrm{d} \sim \mathrm{f}$ : Coagulant $\mathrm{H}_{2} \mathrm{SO}_{4} 4 \mathrm{~N}$, Draft ratio 1.3

Draw ratio $1 \sim 3$

g i : Coagulant $\mathrm{H}_{3} \mathrm{PO}_{4} 43 \%$, Draft ratio 2.7

Draw ratio $1 \sim 2.5$

造の相違は, 先の $3.2,3.3$ の結果から教察したよらな 凝固機構で㠜固が進行するものと考兄れば，硫酸㧍よび リン酸浴に抽いては、ドラフトによる張力が分子鎖の引 き伸ばしに作用し，引き伸ばされながら結晶化する。そ れゆ分子間水素結合による結晶すなわち $\beta$-構造から なる結晶が形成されるるのと考える。

b. 凝固剂执よび延伸之二次構造

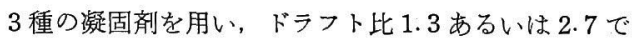
第 1 ロールに巻き,さらに 2 倍 3 倍と延伸した絨維の X 線回折写真を図 5 に示した。

この結果から塩酸凝固浴を用いた織維は, 延伸により 結晶は配向するが, 結晶内の分子鎖は $\alpha$ ーリックスと 思和るるのであることがわかる。硫酸浴による繊維は 延伸により結晶配问が起るとともに，結晶内の分子鎖は $\beta$-構造からなるるのが一部生成することがわかる。り ン酸凝固浴を用いた瀻維は，延伸により結晶内の分子鎖 はほとんど $\beta$ 一構造からなり,わずかに $\alpha$ ーリックスと
思われるものが含まれていることがわかる。実験の範囲 内では最も明瞭な繊維図形を示している。

塩酸凝固浴による緎維は, 凝固浴中で結晶が大部分形 成されているため, 延伸過程では主として結晶配向が起

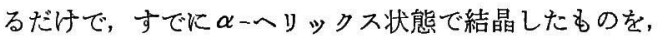
このような延伸により $\beta$-構造の分子鎖からなる結晶に 転移させることは困難のよらである。リン酸を㠜固浴と した場合, 延伸しない状態で結晶化が進んだるの（延伸 比 1.0)では，汪とんどいーーリックスと思われるもの からなる結晶で無配向であるが，2.5 倍延伸したもので は渒とんど $\beta$ 一構造からなる結晶で配向している。した がって㠜固浴中では結晶化は扔乞く，脱溶媒が優先して おこるために，延伸過程でも分子鎖の配向と結晶化が特 こり， $\beta$ ー構造からなる結晶の配向した瀻維となるもの と考完られる。

次に IR による測定結果を図6に示した。IR 法では 全体の分子鎖の形態を反映するので，X線回折法とあわ せて検討する必要がある。

図6の(1)の曲線は图 5 の c の X線回折を与兄る試料の IR スペクトルである。 $1630 \mathrm{~cm}^{-1}$ にわずかな吸收が認 められるので $\beta$-構造を含んでいる。X 線回折写真の上 からも極めて弱、 $\beta$-構造炕上る回折が認められる。(2) は図 5 の $\mathrm{f}$ のX線回折を与兄る試料の IR 曲線で, X線 回折からの結果と同様, $\alpha$-ヘリックスと $\beta$-構造の分子

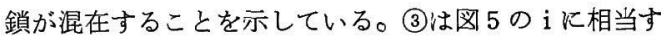
る試料である。X線的にはかすかに $\alpha$ 一、リックスと思 われるものからなる結晶が存在すると思われるが, IR ス ペクトルではほとんと存在しないと思われるので結果が 一致しない。その理由として，錠剂作製時の变化である

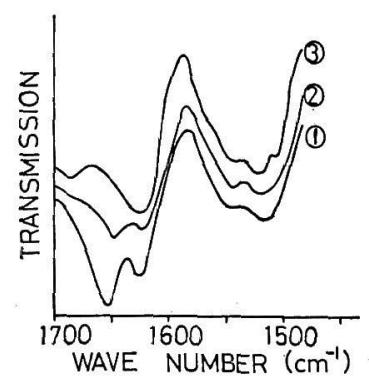

Fig. 6. IR absorption spectra of PGA fibers obtained. by different spinning conditions.

(1) : Coagulant $\mathrm{HCl} 4 \mathrm{~N}$, Draft ratio 1.3

Draw ratio 3.0

(2) : Coagulant $\mathrm{H}_{2} \mathrm{SO}_{4} 4 \mathrm{~N}$, Draft ratio 1.3 Draw ratio 3.0

(3) : Coagulant $\mathrm{H}_{3} \mathrm{PO}_{4} 43 \%$, Draft ratio 2.7 Draw ratio 2.5 . 
か装置の分解能力が悪いためであるかなどが考えられる が，現在の所では明白でない。

以上のよらにリン酸凝固浴を用いることにより，分子 間の凝集力が最も効率よく作用している状態の瀻維とな ることがわかったが，凝固浴として用いた 3 皘類の酸と の化学反応により生成する塩類がそれぞれ異なるため， 塩類の影響を無視できないことは明らかであるので，今 後さらに詳細な検討を試みる予定である。

\section{5 力学的性翼}

凝固浴の種類とドラフト怙よび延伸が瀻維の力学的性 質に括よ注す影響を図 7，8，9 亿示した。

塩酸疑固浴においては, 強度はドラフトによって向上 しないが，延伸により大となる。伸度はドラフトにより むしろ大きくなるが，延伸により小さくなる。硫酸凝固 浴では，強度はドラフト乱よび延伸により大となり，最 高 $1.27 \mathrm{~g} / \mathrm{d}$ であった。伸度はドラフト执よび延伸によ りともに小となる。りン酸凝固浴では, 強度はドラフト 比8.3で最高となり，延伸化より題著に增大し最高 1.7 $\mathrm{g} / \mathrm{d}$ であった。伸度は強度の增大とともに小となり最小 の値は $13 \%$ であった。このように凝固浴の種類により ドラフト特よび延伸効果が相違することがるかった。

このような結果は紡系性, 断面形状, 二次構造扰よび 結晶性などの実験結果から考察した瀻維形成機構で，矛 盾なく説明できるが、ここで得られた最高強度約 $1.7 \mathrm{~g} / \mathrm{d}$ という值について考察する。本実駼使用した原料ポり

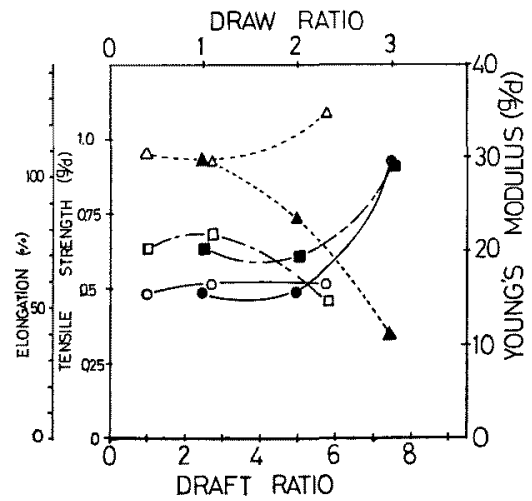

Fig.7. Effects of draft ratio and draw ratio on the mechanical properties of PGA fibers obtained using coagulant $\mathrm{HCl}$.

— : Tensile strength Draft ratio $O$ Draw ratio

:-angation Draft ratio $\triangle$ Draw ratio $\Lambda$

__ : Young's modulus Draft ratio Draw ratio
マーの分子量は約 45000 であったが，数平约分子量と仮 定すると，側鎖の部分が大きいため重合度としては約 300 である。X線回折の結果から， $\beta$-構造の分子鎖か らなる結晶では，1分子鎖当りの長さは約 $3.5 \mathrm{~A}$ であ $ろ^{12}$ からら, 重合度約 300 のものでは分子鎖長約 $1000 \mathrm{~A}$ となる。この值は瀻維としての機能を発揮するために必

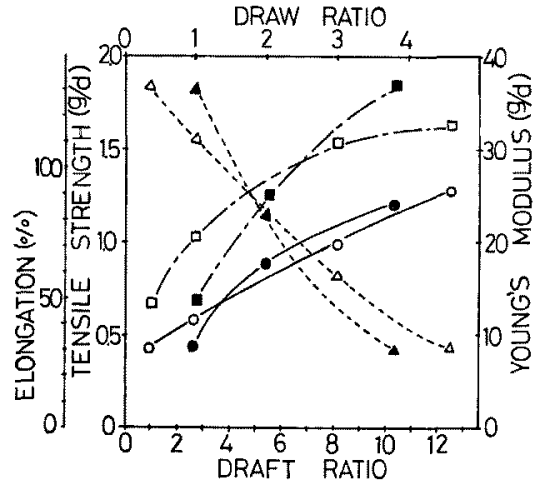

Fig. 8. Effects of draft ratio and draw ratio on the mechanical properties of PGA fibers obtained using coagulant $\mathrm{H}_{2} \mathrm{SO}_{4}$.

- : Tensile strength, Draft ratio $\bigcirc$ Draw ratio

….... : Elongation, Draft ratio $\triangle$ Draw ratio $\mathbf{A}$

-_._: Young's modulus, Draft ratio $\square$ Draw ratio

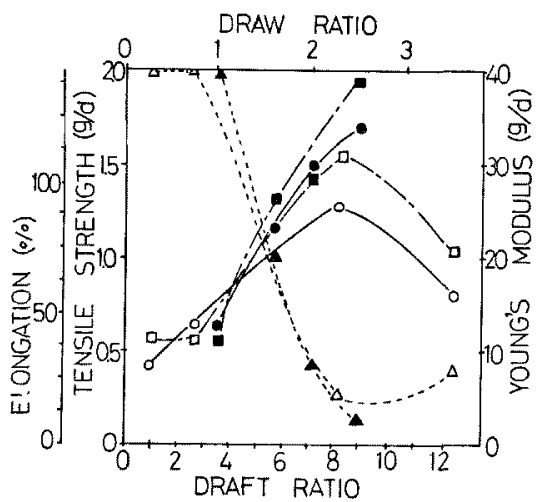

Fig. 9. Effects of draft ratio and draw ratio on the mechanical properties of PGA fibers obtained using coagulant $\mathrm{H}_{9} \mathrm{PO}_{4}$.

-..-: Tensile strength, Draft ratio $\bigcirc$ Draw ratio

Elongation, Draft ratio $\triangle$ Draw ratio $A$

_...... : Young's modulus, Draft ratio Draw ratio 
Table 5. Mechanical properties, secondary structure and crystallinity of PGA fibers obtained by different spinning conditions.

\begin{tabular}{l|c|c|c}
\hline $\begin{array}{l}\text { Coagulant, conc. } \\
\text { Draft ratio }\end{array}$ & $\begin{array}{c}\mathrm{HCl}, 4 \mathrm{~N} \\
\mathrm{H}_{2} \mathrm{SO}_{4}, 4 \mathrm{~N}\end{array}$ & $\begin{array}{c}\mathrm{H}_{3} \mathrm{PO}_{4}, 43 \% \\
1.3\end{array}$ \\
$\begin{array}{l}\text { Draw ratio } \\
\text { Tensile strength } \\
(\mathrm{g} / \mathrm{d})\end{array}$ & 0.91 & 1.20 & $\begin{array}{c}2.7 \\
2.5\end{array}$ \\
\hline $\begin{array}{l}\text { Elongation (\%) } \\
\text { Yong's madulus }\end{array}$ & 34 & 30 & 13 \\
\hline Secondary & 29.2 & 36.8 & 38.6 \\
\hline structure & $\alpha$-helix & $\begin{array}{c}\alpha \text {-helix } \\
+\end{array}$ & $\begin{array}{l}\beta \text {-coil } \\
\text { contain } \\
\text { slightly } \\
\alpha \text {-helix) }\end{array}$ \\
\hline Crystallinity & low & middle & high \\
\hline
\end{tabular}

要な分子鎖長の最低限界と考えられるので强度が小さい 多のと思わ机る。

正確な数平均分子量を求め珫いと，分子鎖長との関係 走論ずることはできないが，重合度が小さいとい5こと か゚，かなり强度比影しているものと思われる。また継 維の強度は他の因子が大い、関係するので，これらに閶 して今後検討する予定である。

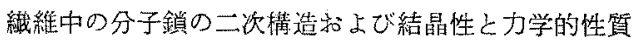
との関係について考察する。年の関係は表 5 のよにな る。壏酸表凝固浴とした場合の上ら比， と思われる分子鎖からなる結晶でかつ配问の悪いもの蚛 强度が小さく伸度が大である。ン酸を㠜固浴とした場 合のようK， の上いものは，強度が大で伸度が小であることがわか る。硫酸を凝固浴ししたものはるょらどその中間的な関 係が荡る。したがって, 編㵶維他近い力学的特性を持つ

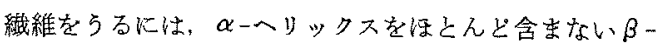
構造の分子鎖からなる結晶を形成するような絬系条件を 選定すべざあることが考えられる。主要な才学的等性 ならびに一次楛造, 二次構造から判断すれば, 塩酸㠜固

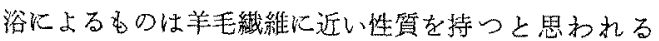

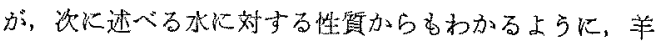

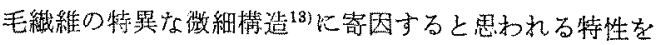
出すことは難かしい課題であると思ら。

\section{6 熱水収縮率}

ポリグルタミン酸のアミド基は分子内苛るいは分子間

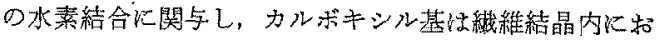
いても自由な状態にあると推定される。したがってこの 親水性基に基つく学動はこの緎維の特に重要な性質であ る。熱水に刘する収縮性もその一つである。

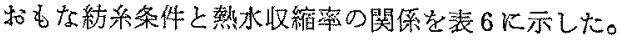

Table 6. Shrinkages, in water at $98^{\circ} \mathrm{C}$, of $\mathrm{PGA}$ fibers obtained by different spinning conditions.

\begin{tabular}{l|c|c|c}
\hline Coagulant, conc. & $\mathrm{HCl}, 4 \mathrm{~N}$ & $\mathrm{H}_{2} \mathrm{SO}_{4}, 4 \mathrm{~N}$ & $\mathrm{H}_{8} \mathrm{PO}_{4}, 43 \%$ \\
Draft ratio & 1.3 & 1.3 & 2.7 \\
Draw ratio & 2.5 & 3.0 & 2.5 \\
\hline Shrinkage $(\%)$ & 16.8 & 12.3 & 9.5 \\
\hline
\end{tabular}

これから塩酸凝固浴化よるのは取縮が最る大きく、り ン酸在㠜固浴としたるの性も小さいことがわかる。 この結果は分子鎖の形態と関連して教劣ることができ る。すなわら く， $\beta$-榡造からなるもの程小さいるのと考えることが できる。 デル・ワールスカのみで結ばれているため凝集力が小さ く，外力により容易に動かされやすい。したがって膨潤 収縮に上る変化が大きいるの之解额できる。また塩酸凝 固浴による擮維は，湿潤加らの乾燥に上り繊維間の固着

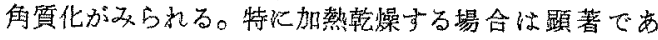
る。このような現象も上述のよ5な理由によるすのと解 䐆できる。湿潤状態に扮ける加熱见上り一部分子鎖の溶

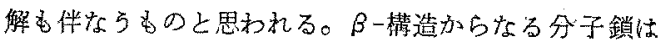
分子間水素結合光作りやすく，容易結晶化し結晶化度 あ高くなる。したがって分子凝集工ネルギーが高い状熊 飞あり，膨㵎收縮による変化が小さいるのと解积でき る。リン酸を凝固浴とし，適当にドラフトを行ない，夼

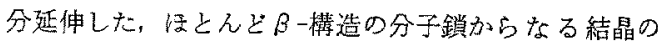
配向した䋘維では，湿潤次態で加熱しても瀻維間の固着 角質化は全く双られないここのよらな現象も同様な理由 によるものと思われる。

\section{4. 結語}

ポリク゚ルタミン酸纎維の湿式紡采に就いて，塩酸，硫

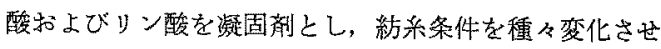
て得られた瀻維について検討した結果次のことがわか。 to

(1)モデル系により㠜固状熊を検討した結果，㩜酸によ るものは白化し柔軟性にとぼしいが，リン酸では透明で

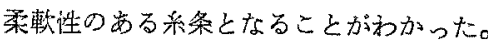

(2)紡系性は 3 種の凝固酸のらちでは塩酸が小さく、y ン酸が最も大きいことがわかった。

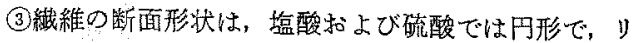
ン酸では亜鉿型であることがわかっだ。

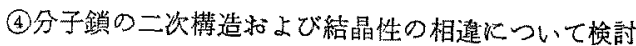
した結果は次のよらであった。原液をノズルから押し出 し凝固したものは，酸の種類によっては相違せずいずれ 


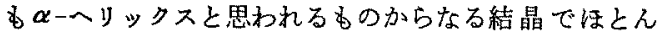
ど無配向であった。ドラフト括よび延伸炕より，塩酸の 場合は二次構造に変化はみられないがわずかに結晶配向 する。りン酸においてははとんどー粫造の分子鎖から なる結晶を形成し，かつ配问の上いるのとなる。硫酸で は $\alpha$-ヘリックスと $\beta$-構造の分子鎖の混在する前 2 者の 中間的状熊になることがわかっだ。

(5)力学的性質は凝固酸の種類和上び紡系条件に上り広 く異なり，一般的に $\alpha$ーーリックスからなる瀻維の強度 は小さく伸度が大きい。及一構造の分子鎖からなる㵶䊒 は強度が大で伸度が小であるといえる。

(6)熱水に対する性質の相違は明白で，塩酸㧍よび硫酸 によるものは熱水収縮が大きく固着角質化するが，リン 酸凝固浴に上るほとんどß-構造からなるものは収縮む 少なく固着角質化も見られなかった。

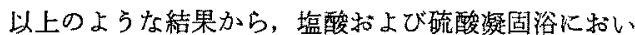
ては、PSLG から PGA に变化する化学反応に上る凝固 が僈先し，脱溶媒による㠜固が湿いすのと考之，これに

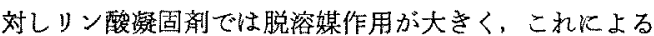
ゲル化凝固が優先し， $\mathrm{H}^{+}$による化学反応性招そいもの と考帛た。このような化学反応による凝固が優先する場 合と脱溶媒による凝固が優先する場合とによって, 形成 される繊維の構造ならびそ諸性質が相違するものと考察 した。

本報ではポリグルタミン酸繊維の湿式紡系条件と系質 との関佰のらち一部分の及を報告したが，原料ポりマー をはじめ湿式紡系には教多くの因子があるので，これら とついて検討した結果ならびに瀻維の結晶構造, 吸湿性 染色性などの諳性質について検討した結果を続いて報告 する予定で㛎る。

付記：本研究の一部は昭和45年 7 月策16回高分子研究 発表会（神戸）招上び昭和45年10月織維学会秋季大会飞 括いて発表した。研究に当りご協力いただいた京都工芸
瀻維大学黑沢喜一郎, 小西孝, 青木一三, 川口恶重, 杉 井新治の諸氏ならびに，陚料を提供していただいた協和

酸醉工業株式会社に深く感謝致します。

文献

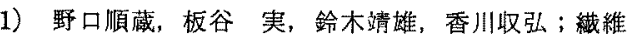
科学研究所年報, 17，30（1964），石川左武郎； 高分子，14，1078(1965)，桜井節二；高分子，18， 9 (1969)，武内民男; 械維工学，22，500 (1969), H. Mark : "Man-Made Fibers" Vol. II, Interscience, New York (1967)，野口順蔵; 高化，27, 145 (1970), 高分子, 20, 518 (1671).

2） Belg.P. 577609 ，591015，B.P. 864692 ，日特公昭 40-5926，昭41-6608，昭42-25505

3）日特公昭 40-11170，昭40-27494，昭41-10832

4）武内民男，高橋重三，川口惠重, 山崎 隆, 相宅 省吾；昭和 45 年瀻維学会秋季大会要旨集 p. 140 (1970)，昭和 46 年瀻維学会年次大会要旨集 p. 189 (1971)，第 17 回高分子研究発表会（神戸）要 旨 p. 86 (1971).

5) A. Wada; Mol. Phys., 3, 409 (1960)

6）瀻維学会編，緎維の形成上構造の発現（II）(化学 同人) (1970)

7）たとえば, L. Pouling, R. B.Corey ; J. Am.Chem. Soc., 71，5349（1950)，和田昭允；高分子， 8, 114 （1959），伊萟村寿三汪加; 新しい生物物理化 学研究法（下）(化学同人) (1967)

8）山崎 隆, 高橋重三, 武内民男, 相宅省吾; 昭和 46年䋐維学会年次大会要旨集 P. 191 (1971).

9) A. Wada ; J. Polymer Sci., 45, 145 (1960), 日 特公昭 40-5926

10) P. Doty, A. Wada, J. T. Y Yang and E. R. Blout ; $J$, Polymer Sci., 23，851 (1957), 和田昭尤; 日化 誌, 78, 1393(1958), 吳 祐吉, 近藤慶之, 青山 㢬一; 高化, 25, 344 (1968)

11）伊勢村筹三注か；新しい生物物理化学研究法(下) p. 59 (1967), 哭 祐吉, 近藤磨之, 青山絃一; 高化，25，344（1968）

12）小酉 孝, 高橋重三, 山畸 隆, 黑川昌孝; 昭和 46 年䋐維学会秋季大会発表 (1971)。

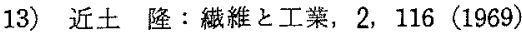

